\title{
BOOK FORUM
}

Austro-Hungarian War Aims in the Balkans during World War I, by Marvin Benjamin Fried, Basingstoke, Palgrave Macmillan, 2014, 294 pp., £63.00 (hardback), ISBN 978-1137-35900-1

\section{The empire strikes back}

\author{
John Paul Newman \\ johnpaul.newman@nuim.ie \\ CJohn Paul Newman
}

I am delighted to accept the invitation from the editorial board of the Journal of Genocide Research to discuss Marvin Fried's new book. I have read the book as carefully and closely as possible. Nevertheless, as is often the case, my comments are to a great extent a reflection of my own research interests and their intersections with Fried's book. The book made me think again about the critical relationship between Austria-Hungary and Serbia, and it also got me thinking about the trajectories between the First and Second World Wars in the Balkan region, and of the possibility of comparing cultures of violence in 1914-18 with those of 1941-45. There is much more to be said about the many topics that Fried's book raises, and no doubt other contributors will pick up on points that go unmentioned here.

Let me first give the work its due praise. Fried's monograph is a fine example of the small renaissance taking place in the field of diplomatic history in recent years. It is based on meti- culous research conducted in archives across central Europe and in several languages. Fried demonstrates a keen understanding of the discussions about how and why political and mili- tary elites conduct war in the modern period. In this respect it is reminiscent of Christopher Clark's major study of the origins of the First World War, The Sleepwalkers, and it will undoubt- edly be mentioned alongside this work in forthcoming discussions of the diplomatic history of the First World War. ${ }^{1}$ Like The Sleepwalkers, Fried puts Austria-Hungary and the Balkans at the centre of the narrative of the First World War. No longer a secondary player or waiting in the wings as the real action takes place elsewhere, Austria-Hungary is now a primary protagonist in the war's drama; and the Balkans are centre stage. The following formulation summarizes fairly well how far Fried wishes to rewrite the traditional script of the First World War: 'if Austria-Hun- gary's willingness to stand by its German ally until the end kept Germany in the war by allowing it to fight on without encirclement, Vienna's Balkan aspirations had kept Austria-Hungary in the warin the firstplace' (p.3; and, with minorchanges,p.232). This was of decisive importance for the demise of Austria-Hungary too: 'consistently offensive war aims in the Balkans ... helped lead to the eventual destruction of the Empire' (p. 3). These are bold and challenging claims both on the international history of the First World War and on the late history of the Habsburg Empire.

Along with comparisons to Clark's opus, Fried's book can be read alongside the new his- tories of late Habsburg history that seek to dislodge narratives of the monarchy's 'eternal decline' down the centuries. I am thinking here of the work of Pieter Judson, Tara Zahra, John Deak, Alexander Watson, Mark Cornwall and Jonathan Gumz. They all challenge the cliché of the 'empire without qualities' (Clark's modification of Musil's great work) - the imperial anachronism that can no longer compete in a world where the masses are supposedly loyal 
exclusively to their nation, not to anything as passé as an emperor and his supranational insti- tutions. The monarchy's military failures, and of course its collapse, have until recently led many historians of the warto denyithistorical agency. But agencyithad, as Fried convincingly shows, and war aims, too, aims that were broadly and flexibly adumbrated during the wars years, but which were nevertheless present.

Fried's close reading of the diplomatic sources also reveals some important differentiation between the various organs of Austro-Hungarian foreign policy and their competencies. I am personally grateful to Fried for showing the extent to which the monarchy's policies in the Balkans remained the preserve of the civilian-controlled Austrian Foreign Ministry (Ministerium des Äussern, or MdÄ) as opposed to the more bullish Military High Command (Armeeoberkom- mando, or AOK, which was responsible for the administration of occupied Serbia). On this point Fried contrasts Austria-Hungary with its wartime ally, Germany, a state in which the war allowed military leaders to achieve an all-encompassing competency over foreign policy. Austria-Hun- gary's disjointed and overlapping political structures serve as checks and balances on what Isabel Hull has in the German context described as the 'institutional extremism' of the army. ${ }^{2}$ It seems that in the AustroHungarian case, the intent and the single-minded focus on a foreign policy aim, desired above all else, is present, just as it is in Germany, but the same extremes are never reached. Fried's treatment of a winter 1915 debate about Serbia's future (one of many throughout the course of the war) is notable in this respect. Austro-Hun- garian Chief of Staff Conrad von Hötzendorf pushes for outright 'removal' of Serbia from the map of Europe, a punitive move to eliminate a rival and to make its fate an example for other potentially nettlesome Balkan states. His hawkish ambitions are thwarted by the more moderate voices in the foreign office (p. 126).

Hull's point about the institutional extremism of the German army in the First World War, of course, is that it presages the extremism of the Second World War. Comparisons between the violence of the First and Second World Wars have occupied historians of the twentieth century, especially, and understandably, historians of Germany. But in the case of the Balkans it is much harder to draw out comparisons between the two world wars. This is partly because there is no obvious sequel to AustriaHungary's First World War Balkan campaigns and policies, no clear institutional continuities between 1914-18 and 1941-45. Incidentally, that has not stopped some historians in the past from making such comparisons. Indeed, the term 'genocide' has been invoked more than occasionally to describe the behaviour and the policies of the Austro-Hungarian military occupation of Serbia and the military administration of Bosnia (especially under the command of Habsburg general Stjepan Sarkotić). This is another historical cliché: it must be clear by now that no such genocidal policies or intent existed. However oppressive and violent many aspects of the Austro-Hungarian occupation were in the Balkans, this is quite unlike the Ottoman treatment of its Armenian population. Even in the wake of defeat and facing oblivion, the Habsburgs make no systematic attempt at elimination. Oppression, even at its worst, seems to be restricted to cultural and political elites, and also to AustriaHungary's (quixotic, I think) attempts at 'de-nationalizing' Serbia through suppression of its educational, political and cultural life. A crime of colonial oppression no doubt, but hardly genocide. The neighbouring Bulgarian occupation was significantly more violent, especially during the so-called 'Toplica Uprising' of 1916, an uprising that broke out following a Bulgarian attempt to conscript Serbians into the Bulgarian army.

Should we desist, then, in comparing the two world wars in the Balkans? Ido not think that the trail runs completely cold with the demise of the Austro-Hungarian Empire in 1918. Ben Shepherd has done some fascinating work on former Habsburg officers, veterans of the Balkan campaigns in the First World War, who were re-mobilized into the Wehrmacht in the Second World War and fought again in occupied and dismembered Yugoslavia. ${ }^{3}$ There is 
also the fact that Austria-Hungary employed disproportionately large numbers of South Slav officers in its Balkan campaign in the First World War, in many cases as intelligence officers whose familiarity with the language made them invaluable. A significant number of these offi- cers 'graduated' into the Ustaše, the Croat paramilitary-terrorist organization formed at the end of the 1920s and which later became ruler of the fascist 'Independent State of Croatia' from 1941 to 1945. We still do not fully understand the role of these officers in the Ustaše's undoubtedly genocidal policies in the Balkans. I suspect that in most cases they balked at this new revolution- ary violence precisely because it was such a far cry from the military norms they had experi- enced last time around. So again, this could be a comparison of difference between Germany's trajectory in the first half of the twentieth century and that of Austria-Hungary and its various successors.

Finally, Fried uses the term 'existential' quite often, usually to describe Austria-Hungary's pursuit of Great Power status that was fundamental to its Balkan policies. Territory equals power equals prestige - this is a comprehensible formulation given the nature of the times and of the Russian threat in the Balkans. I also think, however, that once war began, Austria- Hungary was waging an existential battle of ideas against its implacable opponent, Serbia, a state that represented a very dangerous and different kind of political ideology to that of the multinational AustroHungarian Empire, that is, the ideology of what Rogers Brubaker has termed the "nationalizing state'. ${ }^{4}$ Serbian political and military elites wanted to maintain the momentum of their own nationalizing mission; they too wanted more territory, in the Ottoman Balkans and, of course, in Habsburg Bosnia. Given the asymmetrical nature of any putative battle between Serbia and AustriaHungary, the Balkan state could not rely upon mili- tary means alone: they used clandestine nationalist groups such as 'National Defence' and the Četnik guerrillas to undermine imperial influence and to win over the loyalties of the Slavic populations of those territories. They wanted to persuade the people there that there was no future for them in the Dual Monarchy. The Habsburgs wanted to do precisely the opposite, and with the onset of the war this became an existential battle about the validity of the Habs- burg monarchy in the European state system. The Habsburgs needed to control the Balkans, I think, not simply because they wanted to assert their foreign policy aims over those of their opponents, but also because they wanted to assert their state idea over that of their enemies. This is not to argue that empire and nation are diametrically opposed to one another-few historians of the late Habsburg period would at this stage argue in favour of such stark binary oppositions - but rather that the Habsburgs needed, in the words of Robin Okey, 'tame Balkan nationalism' so that it could operate within the boundaries of the imperial framework. In order to secure the loyalty of their own South Slav population, the Habsburgs needed to make an example of Serbia. This was also at stake in the First World War.

\title{
Achieving war aims through genocide?
}

\author{
Samuel Foster \\ samuel.foster@uea.ac.uk \\ (C)Samuel Foster
}

Adapted from the author's doctoral thesis and published to coincide with the centennial commemoration of the outbreak of the First World War, the publication of Marvin Fried's AustroHungarian War Aims in the Balkans during World War I can be regarded as timely and relevant since it covers the subject from a unique angle. The years preceding this anniversary witnessed a revival of interest in the longstanding debate concerning its origins. Scholarly works such as Christopher Clark's The Sleepwalkers or Sean McMeekin's The Russian Origins of the First World 
War $^{5}$ concentrated on the assassination of Archduke Franz Ferdinand on 28 June 1914 and the escalation of events during the subsequent 'July Crisis'. Rooted in conflicting lines of historic discourse, originating in the 1920s, the surfeit of recent literature represents a retreading of the interwar debate which tended to emphasize the escalation towards war, rather than objec- tives pursued by its various participants once it was underway.

As Fried observes in his opening remarks, the wartime policies pursued by the Dual Monar- chy (or simply the Monarchy) receive, at best, passing mention after August 1914. This approach, the author argues, stems from historiographical trends that followed in the wake of Fritz Fischer's controversial Griff nach der Weltmacht in $1961 .{ }^{6}$ Fischer's main contention, that Wilhelmine Germany instigated the war in a bid for global domination, placed the ques- tion of war aims- 'the territory, military, economic, or other benefits expected following the successful conclusion of a war' (p. 3) - at the centre of the historical debate. As well as those of Germany, the war aims of Britain, France, Italy, Russia, the USA, the Ottoman Empire and even smaller participants such as Serbia and Bulgaria have since come under scrutiny. Austria-Hungary remains the notable exception. Fried attributes this to the enduring percep- tion that, by 1914, it had become 'a mere "corpse", shackled to its powerful German ally and entirely dependent on it for survival' (p. 1). Habsburg diplomats, notably the ambassador to the USA, Constantin Dumba, propagated this view from the war's outset, which led to its con- tinued acceptance among scholars. ${ }^{7}$ The Austrian military historian Manfred Rauchensteiner has previously argued that Austria-Hungary had no genuine foreign policy goals beyond sur- vival. The invasion of Serbia in July 1914 was simply a punitive measure against 'Greater Serbian nationalism'. Fearing that it would push the Dual Monarchy's state apparatus beyond its political tolerances, neither Vienna nor Budapest had any desire for further territorial expansion. ${ }^{8}$

Fried seeks to disprove these prevailing assumptions by setting aside the issue of responsibility for the war's outbreak - and to whom blame should be apportioned - focusing instead on the role Austria-Hungary's leaders played in its actual prosecution. Far from having no inde- pendent policies beyond preserving the House of Habsburg-Lorraine's polyglot imperium, a coterie of the Monarchy's most powerful military and political leaders adopted the notion of wartime expediencies as a means of furthering a set of expansionist war aims. In contrast to the mainly defensive campaigns fought in Galicia and along the Italian border, territorial ambi- tions were centred exclusively on the one region regarded by both Vienna and Budapest as the Monarchy's rightful sphere of influence, namely the Balkans. Initially targeting Serbia alone, the proliferation of this 'local conflict' into a general European conflagration prompted the ruling elite to update pre-existing plans for contiguous expansion to cover as much of the region as possible, specifically Albania and Montenegro. These plans were modified as the war pro- gressed, yet the primary motivation remained the acquisition of territory and political influence in the Balkans. It was the relentless pursuit of these war aims, Fried contests, that served to prolong the wider war at immense human and material cost.

In terms of structure, Austro-Hungarian War Aims in the Balkans during World War I follows a linear chronological analysis. The first and second chapters outline the historiography, current state of war aims research and, most significantly, explain how the Monarchy's foreign policy and military apparatus decided and shaped its war aims. Despite possessing a central foreign ministry (the Ministerium des Äussern, or MdÄ) and Military High Command (the Armee Ober- kommando, or AOK) the dualist nature of Austria-Hungary's governance had evolved to give the prime minister of its Hungarian portion a disproportionate level of influence over foreign policy. It was these three ministries - or rather those ministers who controlled them

—officially overseen by the Habsburg emperor through his Military Chancellery (the Militärkan- zlei Seiner Majestät, or MKSM), that formed an 'inner core' with almost exclusive power to 
determine and set war aims. Indirect power was also exercised by several concentric tiers of influence. These included other domestic, military and political structures and personages; the various military governances set up in occupied Balkan territories; and Austria-Hungary's wartime allies (p. 8). The main body of the book (chapters three to seven) follows the pro- gression of the war in several stages, examining how the complex interplay between these tiers influenced the inner core's constituent elements.

At its crux, Fried's analysis is a history of the interpersonal relationships, competing motives and ambitions of Austria-Hungary's wartime leadership. Unsurprisingly, war aims excluded the involvement of the citizenry while, under the octogenarian emperor Franz Joseph I, the MKSM exercised only nominal authority serving more as an arbiter between the AOK and MdÄ. War aims were therefore determined almost entirely by four key figures: István Tisza, the Hungarian prime minister; Franz Conrad von Hötzendorf, who headed the AOK; and the MdÄ foreign min- isters Leopold Graf, until his forced resignation in January 1915, and his successor Stephan Burián von Rajecz. Such was the influence wielded by these policy-makers that, by 1916, a 'Burián-TiszaConrad triumvirate' held power almost to the exclusion of the wider government and even the emperor (p. 135). Following the succession of Franz Joseph's great-nephew Karl I to the throne in November 1916, those who had formed this triumvirate were either dismissed from their governmental posts or politically weakened. However, despite unsuccessful moves to disengage Austria-Hungary from the war, its leaders remained partially wedded to the concept of Balkan war aims, even as the Monarchy began to implode.

The most intriguing aspect of Fried's study is his exposure of the level of incoherence and dysfunctionality within the Monarchy's ruling echelon. Accordingly, his analysis identifies two types of war aims that determined all decision-making. These were 'positive war aims', which sought tangible outcomes (mainly territorial), and 'negative war aims', aimed at forestalling or preventing wartime successes for Austria-Hungary's neighbours. Problems arose almost immediately as those responsible for planning often held widely differing opinions over which 'negative war aims' demanded greater priority. Hungarian politicians such as Tisza and Burián perceived the Dual Monarchy as a protective carapace for preserving the integrity of its Magyar portion: Transleithania. Thus Romania, the principle contender for Transylvania and other Hungarian-ruled territories, dominated their own war aims planning. By contrast, Austrian-orientated leaders such as Conrad were preoccupied with undermining Italian efforts to usurp the Monarchy as southeastern Europe's regional hegemon.

Even the achievement of ostensibly positive war aims (such as the eventual conquest of Serbia with German and Bulgarian assistance in October 1915) could precipitate further argu- ments and dissent. Individuals and factions within the leadership often resorted to blackmail and bullying tactics in order to push their own agendas and outmanoeuvre rivals. Conrad attracts particular criticism for his aggressive posturing and proclivity to openly defy or interfere in the edicts of the MdÄ.

The line between positive and negative war aims became increasingly blurred as the Mon- archy's ambitions in the Balkans conflicted with those of its allies. Despite playing a decisive role in the Central Powers' defeat of Serbia, Bulgaria was regarded more as a potential threat. Its own policies for a 'Greater Bulgaria' clashed directly with Austria-Hungary's, whose leaders deemed any expansionist Slavonic Balkan state, as Serbia had been, to be a future risk to Habsburg security and regional 'prestige'. Following Serbia's occupation, tensions between the two Balkan powers deteriorated almost immediately. A diplomatic crisis, resulting from Bulgarian attempts to expand into Kosovo between February and April 1916, threatened to erupt into internecine conflict between the two erstwhile allies (pp. 144-153). The Balkans also placed strain on Habsburg-German relations. The region was not a primary concern for Berlin, whose own war aims did not complement those of Vienna and Budapest. As with 
Bulgaria, relations were marred by suspicion and mistrust. In October 1915, for example, the Monarchy was obliged to implement measures restricting the German army's exploitation of areas of Serbia which briefly fell under its control (pp. 113-115).

Utilizing a wide range of Austrian, German and Hungarian archival sources, alongside memoirs and secondary literature, Fried's understanding of this much neglected topic is as erudite as it is extensive. Nevertheless, the book is not without minor faults. Firstly, although Fried threads his arguments throughout the narrative with lucidity, the text often feels encum- bered by the abbreviations used to denote the various competing agencies. In several instances, MdÄ is used interchangeably to denote either whoever happened to hold the office of foreign minister or the ministry itself. The MKSM appears to be missing from the abbreviations list (pp. xvi-xvii), although this may be a simple matter of editorial oversight. Fur- thermore, while the inclusion of a map of the Balkans highlighting the portions of territory that the Monarchy particularly coveted in 1914 (p. xviii) is a welcome feature, the book would have benefitted from additional illustrations depicting the region following the occupations of Serbia and Montenegro and the period prior to AustriaHungary's collapse in October 1918.

With all thisin mind, how should one approachAustro-Hungarian War Aims in the Balkans during World WarIfrom the perspective of whether ornot genocide wascommitted by the centralEuro- pean power(as is often claimed in Serbian sources)? Fried is writing about a period that preceded genocide's codification as a legal concept by three decades. In these instances, an accepted trend has been to label retroactively any pre-dating occurrences deemed to comply with its legal defi- nition. Far more commonly identified, however, are those non-genocidal, though noless abhorrent acts known as war crimes. Prior to 1914, a series of international laws regarding the rules of war- which aimed to mitigate war crimes against both combatants and non-combatants - had been laid out in the Hague Conventions of 1899 and 1907. The historian of photography Anton Holzer has written an intriguing study of the culture of war crimes, but relatively little has yet been written on crimes committed by Austro-Hungarian (or Bulgarian) forces during the First World War. ${ }^{9}$ This could be ascribed to a lack of primary information. Most contemporary under- standing comes from reports authored by the Swiss-German criminologist Archibald Reiss, who conducted surveys of war crimes committed against the Serbs by the Central Powers during the invasions of 1914 and 1915. Alongside mass killings, both reports allege that the civilian populace had been subjected to looting, mass rape and various tortures similar to the reported atrocities of the Balkan Wars from 1912 to 1913. In terms of scope, these alleged atrocities paled incomparison with those later perpetrated within the Bulgarian zone of occupation. Nevertheless, such actions, Reiss contested, amounted to a systematic violation of the Hague Conventions - the Monarchy being a signatory to both. $^{10}$

Admitting certain atrocities, such as the burning of Serbian houses in reprisal for attacks on Habsburg forces, andeven 'realmassacres', such as thekilling of civilian prisoners in the city of Šabac in August 1914, Rauchensteiner argues that his reports can be 'discounted as propa- ganda' for only investigating Serbian allegations against Austria-Hungary. ${ }^{11}$ Nevertheless, scho- lars have in the main acknowledged his findings as factual; the question is whether such war crimes amounted to genocide. Alan Kramer asserts that such tactics constituted a 'war of destruction' that the Monarchy deemed necessary for its own survival. As a result, Serbia pro- portionally experienced some of the highest military and civilian casualty rates of any of the war's combatants. ${ }^{12}$ Fearing that the Central Powers would seek to wipe out their nation com- pletely, in 1915 the fleeing Serbian army was believed to have taken with it 30,000 young boys, as a matter of racial preservation. Andrej Mitrović describes Austro-Hungarian war aims as indicative of an imperialism that sought to economically exploit the Monarchy's Balkan acqui- sitions while attempting to extinguish Serbian, Montenegrin and by extension Southern Slav identity. ${ }^{13}$ More recently, Jonathan Gumz has attempted to relativize Reiss's claims by 
attributing these crimes to a breakdown in military discipline, rather than the physical destruc- tion of the Serbian people. Unlike Rauchensteiner, however, Gumz does admit that the reced- ing of discipline precipitated widespread atrocities and that Reiss's report on the numbers killed $(3,500$ 5,000 in 1914) represents the only reliable estimates produced by either side. ${ }^{14}$ Even if such atrocities did not in themselves represent plans for racial extermination, one can begin by asking Fried the extent to which the Monarchy's leaders were aware of them. Were such actions permitted or tolerated as part of war aims planning or did the AOK simply fail to exercise control over Oskar Potiorek and other commanders? If the former, then could the author perceive of a case for charging Berchtold, Conrad, Tisza and others as party to war crimes, or at least allowing for their facilitation?

Genocide itself does not necessarily entail driving a particular ethnic group to complete bio- logical extinction. In most cases the eradication of a national identity or culture through repres- sion or planned demographic displacement was deemed a more realistic object. A core facet of Jonathan Gumz's thesis is that, between 1916 and 1918, the Austro-Hungarian military regime in Serbia attempted to 'depoliticize' the populace via a range of cultural and economic sanc- tions, such as the banning of the Cyrillic alphabet, in order to erode any sense of a distinctive identity. Teachers, civil servants, intellectuals and any other groups deemed to have served as conduits for nationalism and the politicization of the wider population were dismissed, impri- soned or driven into exile. ${ }^{15}$ Fried hints that the leading personalities considered this approach as both a legitimate means of consolidating the Monarchy's hold over annexed territories and a point of contention between rival sets of war aims. Following the occupation of Serbia, for example, Tisza and Conrad quickly began clashing over its future. Conrad's demands for full annexation were countered by Tisza's insistence that only strategic areas were to be absorbed and transformed into ethnic buffers, based on Germany's 'Grenzstreifen concept'. Under this practice, undesirable Serb majorities were to be diluted through 'generous colonization of Hun- garian and German elements'; the author states that such a solution was 'tantamount to demo- graphic ethnic warfare' (pp. 127-128). Were such strategies deeply embedded in official war aims planning? If so, then how extensively were they discussed and debated and did a consen- sus exist regarding their use before the war's outbreak?

This question of genocide as a tool for implementing war aims leads to one final criticism: that Fried has been tooprecise in hisfocus. Theintroduction states unequivocally that waraims planning existed firmly outside the popular sphere. However, what about those who were responsible for war aims? The late nineteenth and early twentieth centuries had, after all, wit- nessed the rise of extreme modes of thinking. As Frederic Morton observed, Vienna alone was a nexus of new, often extreme, political and social thought. In 1913, no lesser figures than Adolf Hitler, Sigmund Freud, Joseph Stalin, Leon Trotsky, Vladimir Lenin and Josip Broz Tito resided in the city and patronized the same establishments, all very much creatures of its radical intellec- tual milieu. ${ }^{16}$ Would it be inexpedient to speculate that possibly unbalanced figures such as Conrad, a man given to pathological hatreds (p. 26), or those Hungarian statesmen who per- ceived the Monarchy as a vehicle for furthering Magyar nationalism, might also have been sus- ceptible to these new currents of thought? Assuming that the Monarchy did not ensure that its ruling political and military elites were completely insulated from all external ideological influ- ences, how widespread were such beliefs among the staff of the AOK and MdÄ?

Placed in the wider context of the First World War, Fried's narrow focus invariably raises questions regarding how external conditions reflected back onto Vienna and Budapest's corri- dors of power. Conversely, scholars seeking to cultivate an understanding of the human con- sequences of the Monarchy's actions should look to pre-existing literature instead. Nevertheless, AustroHungarian War Aims in the Balkans during World War I should be regarded as one of the singularly most important academic texts to have come out of the centennial 
year. Fundamentally, it opens a new phase in contemporary First World War historiography: who among the war's participants should be apportioned responsibility for continuing to per- petuate it? The paucity of suggestions - in contrast to recent revisionist interpretations con- cerning its origins - implies that this may be a less approachable, or unwanted avenue of enquiry.

\title{
A major contribution to our understanding of the Great War
}

\author{
Eric Beckett Weaver \\ ericbweaver@gmail.com \\ (CEric Beckett Weaver
}

Austro-Hungarian War Aims in the Balkans during World War I is the first comprehensive over- view in English of the shifting and often contradicting views held in Budapest and Vienna. Marvin Benjamin Fried's thick narrative will provide fellow historians with a cornucopia of rev- elationsthe fruit of years of archival research — and with points of dispute and further research. For this, the book cannot be praised highly enough. The critical remarks I make below on specific points are in the nature of wanting more, not less, of Fried's research.

At the outset, Fried outlines the tensions and differences between various players. He dis- cusses the Austro-Hungarian Foreign Ministry, which he has abbreviated as MdÄ, the Minister- ial Council, the emperor, the Hungarian government as represented by Tisza, and the Monarchy's military command, abbreviated as AOK. It takes some time to get accustomed to these abbreviations, and they make the narrative unnecessarily hard going. In places, when Fried writes Mdë, he actually seems to mean the foreign minister alone, while in others he uses it for a panoply of characters.

Fried often uses the shorthand 'the Hungarians', as if he meant all of them. He tells us in his introduction that the Austro-Hungarian foreign minister:

wrestled on the one hand with the army, which sought near-boundless annexations against the Monarchy's adversaries, and on the other hand against the Hungarians, who sought either no annexations or changes favouring only themselves (p.2).

Note the comment contrasting the foreign minister with 'the Hungarians'. In many places Fried is not referring to Hungarians as such, but only to the Hungarian prime minister, István Tisza, whodespite his great power - cannot be taken as representative of all Hungarian views. There were, in point of fact, real differences between influential Hungarians throughout the war, particularly with regards to policies in the Balkans. ${ }^{17}$

This generalization about Hungarians as separate from institutional actors in Vienna is also unfortunate. Things were not so clear. Two examples: the Hungarian István Burián served as the Monarchy's foreign minister from January 1915 to 1916, and again in 1918. Should Burián, therefore, be considered among the Austrians? Far from it. Burián's published diary and corre- spondence with Tisza (largely unpublished) reveal him to have been an ardent Hungarian patriot, who always kept his homeland's interests in mind. Another Hungarian, János Forgách, was also a key figure in the Foreign Ministry - yet Fried separates his views, too, from those of 'Hungarians'. Nonetheless, Fried has done great service in exposing aspects of Burián's and other Hungarians' views that are inaccessible to researchers who do not speak Hungarian.

For many, the first revelation Fried provides will be the repeated and insistent demands for Serbian territory made by Hungarians and, as the war dragged on, further demands made in Vienna and Budapest alike for Montenegro, parts of Italy, Romania and Russia's Polish lands. These territories were demanded despite claims made from the outset by Vienna that the 
campaign was merely punitive, and that there would be no serious annexation of Serbian ter- ritory. Precisely what punishment of Serbia meant was never clarified, though it proved to be horrifically brutal. The claim that there was no desire in Budapest to annex territories with South Slavs, and particularly not territories with Serbs, is one of the oldest and most set ideas of the historiography on Austria-Hungary in the First World War. It originates in declarations made on the very eve of the war and at the outbreak of conflict that Austria-Hungary was acting only out of self-defence, and had no territorial demands. In his introduction to a book published in New York in 1914, Vienna's ambassador to Washington, Constantin Dumba, wrote of the Great War: 'It is not a war waged by a government for its own aggrandizement. It is a struggle for life ...' ${ }^{18}$

After the war, in an attempt to deflect war guilt from Hungary, the point was (and still some- times is) made that Hungary's Prime Minister Tisza (and supposedly, by association, all of Hungary) was the sole individual in the Austro-Hungarian cabinet to initially oppose the war. ${ }^{19}$ Furthermore, the claim was made that Tisza never wanted to annex any part of Serbia because any addition of ethnic South Slavs (especially Serbs) would further undermine Hun- gary's stability.

In his recollections, Count Andrássy wrote that during the war he personally 'did not consider it to be in the interest of the Monarchy to increase the nationalities on a large scale'. Furthermore, claimed Andrássy,

The majority of Hungarian opinion agreed with me on this point, and Tisza, Apponyi and Károlyi took a similar attitude to my own. For this reason alone it is absurd to look for the origin of the war in any Hungarian desire for conquest where only the necessity for defence made Hungary take any part in the outbreak of the war. ${ }^{20}$

After the war and the disintegration of the Monarchy, the claim that Hungary's leaders - Tisza above all — did not want to annex Serbian lands appeared very convincing.

However, Fried conclusively demonstrates that gentlemen in Vienna and Budapest alike most certainly did plan to annex significant territories, most particularly in the Balkans. Particu- lars of this Balkan dimension have already been described in a helpful essay by Mark Corn- wall. ${ }^{21}$ What Fried gives us is a thorough exposé of the constant nature of these demands for territory over the course of the war. As early as 16 November 1914, when Habsburg forces had still failed to conquer Serbia, Tisza was sent on a mission to Berlin to present the Germans with the Monarchy's planned enlargement. Tisza began by claiming he wanted 'as little territorial growth as possible', except for 'very important strategic concerns'. These 'little' changes were to include the addition to Hungary of 'the north-west corner of Serbia, the Negotin circle, and Belgrade'. Fried laconically notes, 'These were by no means small border rectifications' (p. 33). Indeed they were not. Serbia's capital alone had more than 100,000 residents. Disregarding other territories coveted by Tisza, the addition to Hungary of Belgrade would have increased the number of Serbs in Hungary by roughly a quarter. ${ }^{22}$ Here we do not find a statesman who wanted to minimize the South Slav minorities in Hungary, but one who wished to increase them quite significantly.

Fried demonstrates that these territorial demands were no aberration on Tisza's part. As the fortunes of war changed, Tisza continued to claim territory for Hungary and was not above using chicanery to get what he wanted. At one point Tisza infuriated his Austrian counterpart by leaking to the press that he, Tisza, would send only trustworthy Hungarian officials to provide civil administration in occupied Serbian territories. The outraged Austrian premier was to be placated with promises of Polish territory, and 'adjustments' to Austria's favour on the Italian border. Tisza's demands, which included maintaining a small nominally independent 
Serbia in the south, only appear modest in comparison with those of the Habsburg comman- der, Franz Conrad von Hötzendorf, who wanted to annex all of Serbia and Montenegro.

Though Conrad and Tisza disagreed on many things, they thoroughly agreed on the need to punish the Serbs, and to teach them who was to be master. Whether because of Austro-Hun- garian authorities' desire to regulate Serbs or to punish them, by the end of the Austro-Hungar- ian and Bulgarian occupation about one quarter of Serbia's pre-war population was dead. ${ }^{23}$ Punishment indeed.

For comparison: under Pol Pot's regime, roughly the same proportion of Cambodians died in about the same length of time. As for the conclusion of that occupation, and of the Great War - to the bitter end Austria-Hungary upheld territorial demands on its neighbours, even as it became increasingly clear to all that the war was lost. Towards the end of the war, Burián cheerfully noted in his diary that the Austrian and Hungarian prime ministers had just voted to extend the prime Habsburg law, the Pragmatica Sanctio, to Poland. ${ }^{24}$ While Fried, perhaps correctly, ignores this last act of idiocy, the impression Fried gives so devastatingly and convincingly is of a Habsburg leadership absurdly out of touch with reality. Fried notes that Burián did not give up demands for territories in the Balkans until 10 October 1918, after the army had already begun to disintegrate, and just a few weeks before the dissolution of the monarchy (p. 229).

With Austro-Hungarian War Aims in the Balkans during World War I, Marvin Benjamin Fried has joined the very small group of (non-Hungarian) historians of the Habsburg Monarchy able to convey the results of significant research in both of the Dual Monarchy's major languages. This is a major contribution to our understanding of the Great War, and will provide departure points for further research for years to come.

\section{Notes on contributors}

John Paul Newman is lecturer in history at Maynooth University, Ireland. He is the author of a number of articles and a monograph Yugoslavia in the shadow of war: veterans and the limits of state-building 1903-1945 (Cambridge: Cambridge University Press, 2015). More recently he has extended his research interests from South Slav soldiers to veterans from other parts of the Habsburg Monarchy and has recently coedited Sacrifice and rebirth: the legacy of the Great War in East-Central Europe (Oxford: Berghahn, 2016) with Mark Cornwall.

Samuel Foster is currently completing a $\mathrm{PhD}$ on 'Representing the South Slavonic peasants in popular British Discourse, 1900-1941' at the University of East Anglia. He is the author 'The First World War's forgotten front: Salonica 1915-18', forthcoming in 2017.

Eric Beckett Weaver is a lecturer in history and politics at the University of Debrecen and Editor of The South Slav Journal. He is the authorand editor of books including National narcissism: the inter- section of the nationalist cult and gender in Hungary (Oxford: Lang, 2006) and Problems of identities in the Balkans (Belgrade: Anglo-Serbian Society, 2006) co-edited with Slobodan G. Markovich and Vukašin Pavlović.

\section{ORCID}

Eric BeckettWeaver (10) http://orcid.org/0000-0001-9719-5040

\section{Notes}

1. Christopher Clark, The sleepwalkers. How Europe went to war in 1914 (London: Penguin, 2013).

2. Isabel V. Hull, Absolute destruction. Military culture and the practices of war in imperial Germany (Ithaca, NY: Cornell University Press, 2005), p. 5. 
3. Ben H. Shepherd, Terror in the Balkans: German armies and partisan warfare (Cambridge, MA: Harvard University Press, 2012).

4. Rogers Brubaker, 'National minorities, nationalizing states, and external national homelands in the new Europe', Daedalus, Vol. 124, No. 2, Spring 1995, pp. 107-132.

5. Sean McMeekin, The Russian origins of the First World War (Cambridge, MA: Harvard University Press, 2013).

6. Fritz Fischer, Griff nach der Weltmacht, Die Kriegzielpolitik des kaiserlichen Deutschland 1914- 1918 (Düsseldorf: Droste, 1961).

7. SeeforexampleErnestLudwig,Austria-Hungaryand thewar(New York: J.S.Ogilvie, 1914).

8. Manfred Rauchensteiner, 'Österreich-Ungarn', in Gerhard Hirshfeld and Irina Renz (eds.),Enzyk- lopädie Erster Weltkrieg (Paderborn: Schöningh, 2003), pp. 64-86.

9. Anton Holzer, Das Lächeln der Henker. Der unbekannte Krieg gegen die Zivilbevölkerung 1914- 1918 (Darmstadt: Primus 2. Aufl., 2014).

10. See Archibald Reiss, How Austria-Hungary waged war in Serbia: personal investigations of a neutral (Paris: A. Colin, 1915); Archibald Reiss, Report upon the atrocities committed by the AustroHungarian army during the first invasion of Serbia (London: Simpkin, Marshall, Hamilton, Kent \& Co., 1916).

11. Manfred Rauchensteiner, The First World War and the end of the Habsburg Monarchy (Vienna: Böhlau, 2014), pp. 265-266; p. 1051. Rauchensteiner's own research is based largely on official Austrian and Hungarian documents and publications.

12. Alan Kramer, Dynamic of destruction: culture and mass killing in the First World War (Oxford: Oxford University Press, 2007), pp. 140-141.

13. Andrej Mitrović, Serbia's Great War, 1914-1918 (London: Hurst, 2007), pp. 193-244.

14. Jonathan E. Gumz, The resurrection and collapse of empire in Habsburg Serbia, 1914-1918 (Cam- bridge: Cambridge University Press, 2009), pp. 50-59.

15. Gumz, The resurrection and collapse, pp. 62-89.

16. See Frederic Morton, Thunder at twilight: Vienna 1913/1914 (New York: Scribner, 1989).

17. For details on the differences among prominent Hungarians, see Dániel Szabó, A magyar állás- pontok helye a Szerbiával szembeni hadicélok rendszerében (1915-1918) (Budapest: Akadémiai Kiadó, 1976).

18. Constantin Dumba, 'Introduction', in Ludwig, Austria-Hungary and the war, pp. 5-13 (13). Also see similar claims by Julius (Gyula) Andrássy, Whose sin is the World War (New York: New Era Publishing, 1915) and Constantin Theodor Dumba, 'Why Austria is at war with Russia', The North American Review, Vol. 200, No. 706, September 1914, pp. 346-352.

19. The myth about Tisza's pacifism is so commonly held that I have heard it repeated by excellent Hungarian historians on three occasions. In fact, Tisza's opposition was very short-lived, his objection was not against war as such, but only against war at that moment, and he soon became a hearty proponent of the war.

20. Julius Andrássy, Diplomacy and the war (London: J. Bale, 1921), p. 165.

21. Mark Cornwall, 'The Habsburg elite and the Southern Slav question', in Lothar Höbelt and Thomas Otte (eds.), A living anachronism? European diplomacy and the Habsburg Monarchy (Vienna: Böhlau, 2010), pp. 239-270; p. 247 ff.

22. In 1910, Hungary counted 461,516 citizens as 'Serbs'. László Kővágó, A magyarországi délszlá- vok 1918-1919ben (Budapest: Kiadás, 1964), pp. 10-11.

23. On various estimates of Serbia's losses, see Slobodan G. Markovich, 'Serbia's war losses during the Great War reconsidered', in Dragoljub R. Živojinović (ed.), The Serbs and the First World War 1914-1918 (Belgrade: SANU, 2015), pp. 369-381.

24. Báró Burián István naplói 1907-1922: Báró Burián István távirati könyvei 1913-1915 (Budapest: Ráday, 1999), p. 230. 